Bangladesh J. Bot. 49(3): 467-472, 2020 (September)

\title{
SUITABILITY ASSESSMENT OF SOILS OF PANCHAGARH AND THAKURGAON FOR TEA (CAMELLIA SINENSIS L.) AND ORANGE (CITRUS AURANTIUM L.) CULTIVATION
}

\author{
Md Jashim Uddin*, ASM Mohiuddin, Shakil Uddin Ahmed, \\ Mo Khalilur Rahman, Md Abdul Karim ${ }^{1}$ and Ashim Kumar Saha ${ }^{2}$ \\ Department of Soil, Water and Environment, University of Dhaka, Dhaka-1000, Bangladesh
}

Keywords: Suitability assessment, Land and soil, Tea and orange cultivation, GIS

\begin{abstract}
Experiments were conducted in soils of the five Upazilas, namely Atwari, Tetulia, Boda, Ranisankail and Panchagarh Sadar of Panchagarh and Thakurgaon districts of Bangladesh to assess their potentialities for tea and orange cultivation. Geographic Information Systems (GIS) based soil suitability map was prepared depending on the hydrological, land and soil characteristics. It was observed that about 86,76 and $50 \%$ soils in Atwari, Tetulia and Panchagarh Sadar Upazilas, respectively are suitable for tea and orange cultivation. But in Boda and Ranisankail Upazilas above $60 \%$ soils are suitable for cultivation of tea and orange. Besides, five representative soil pedons, namely Bhajanpur, Ranisankail, Pirgachha, Domar and Dimla were studied and compared with the standard suitability formats. The results revealed that soils of the Thakurgaon and Panchagarh districts under the Old Himalayan piedmont plain are suitable for tea and orange cultivation. There is a vast scope of utilizing the land and soil resources of the above sites for tea and orange farming.
\end{abstract}

\section{Introduction}

Sustainable agricultural development depends on the potential land use planning. Land and soil resources should be utilized according to their potentiality (Uddin 2000). Soil information is very vital component in this planning process, reflecting directly upon land use suitability (Coleman and Galbraith 2000). The utility of soil and land resource information for proper and pragmatic agricultural land use was proposed by Dumanski et al. (1987). The land evaluation system of FAO (1983) was based on land qualities as related to individual crops that was used to develop the crop requirements based on experiences in tropical areas (Sys et al. 1993). Soil characterization also helps in documenting soil properties at research sites, which is essential for the successful transfer of research results to other locations (Jenny 1980, Buol et al. 2003). The suitability analysis allows identifying the limiting factor of any crop production and enabling decision makers to develop crop management system for increasing the productivity of the land (Gahlod et al. 2017). The utility of land and soil resources information for proper agricultural land use was proposed by Naidu et al. (2006). Sahu et al. (2014) has developed soil suitability criteria for the major horticultural crops grown for identifying the potential areas for maximizing the production. Advanced digital technology like Geographic Information Systems (GIS) has contributed to speed up the overall planning processes as well. Application of GIS in land use planning was well documented by many authors (Maji et al. 2001, Gahlod et al. 2017).

At present, tea and orange are mainly cultivated in Sylhet and Chittagong Hill Tracts of Bangladesh. Moreover, the potential land for tea and orange in the north-western part of Bangladesh remained unexplored. The success story of growing tea and orange in Darjeeling and Shiliguri areas of India has made the argument that why it cannot be successful in the neighboring areas having more or less similar topographic nature with suitable soils. The poverty level thus can

*Author for correspondence: <mjuddin66@yahoo.com>. ${ }^{1}$ Department of Botany, University of Dhaka, Dhaka-1000, Bangladesh. ${ }^{2}$ Bangladesh Tea Research Institute (BTRI), Srimangal, Moulvibazar, Bangladesh. 
be minimized through cultivation of tea and orange in the vast areas of Panchagarh and Thakurgaon districts by selecting appropriate land and soil resources. An attempt was undertaken to explore the suitable land and soil resources for tea and orange cultivation in the Panchagarh and Thakurgaon districts of Bangladesh.

\section{Materials and Methods}

An intensive field study was carried out in the Upazilas of Tetulia, Atwari, Panchagarh Sadar, Boda and Ranisankail under the districts of Panchagarh and Thakurgaon (Fig. 1). During field study, semi detailed soil survey maps (Scale 1: 50,000) of Soil Resource Development Institute (SRDI) were used as a source map to identify the appropriate land and soil conditions for potential

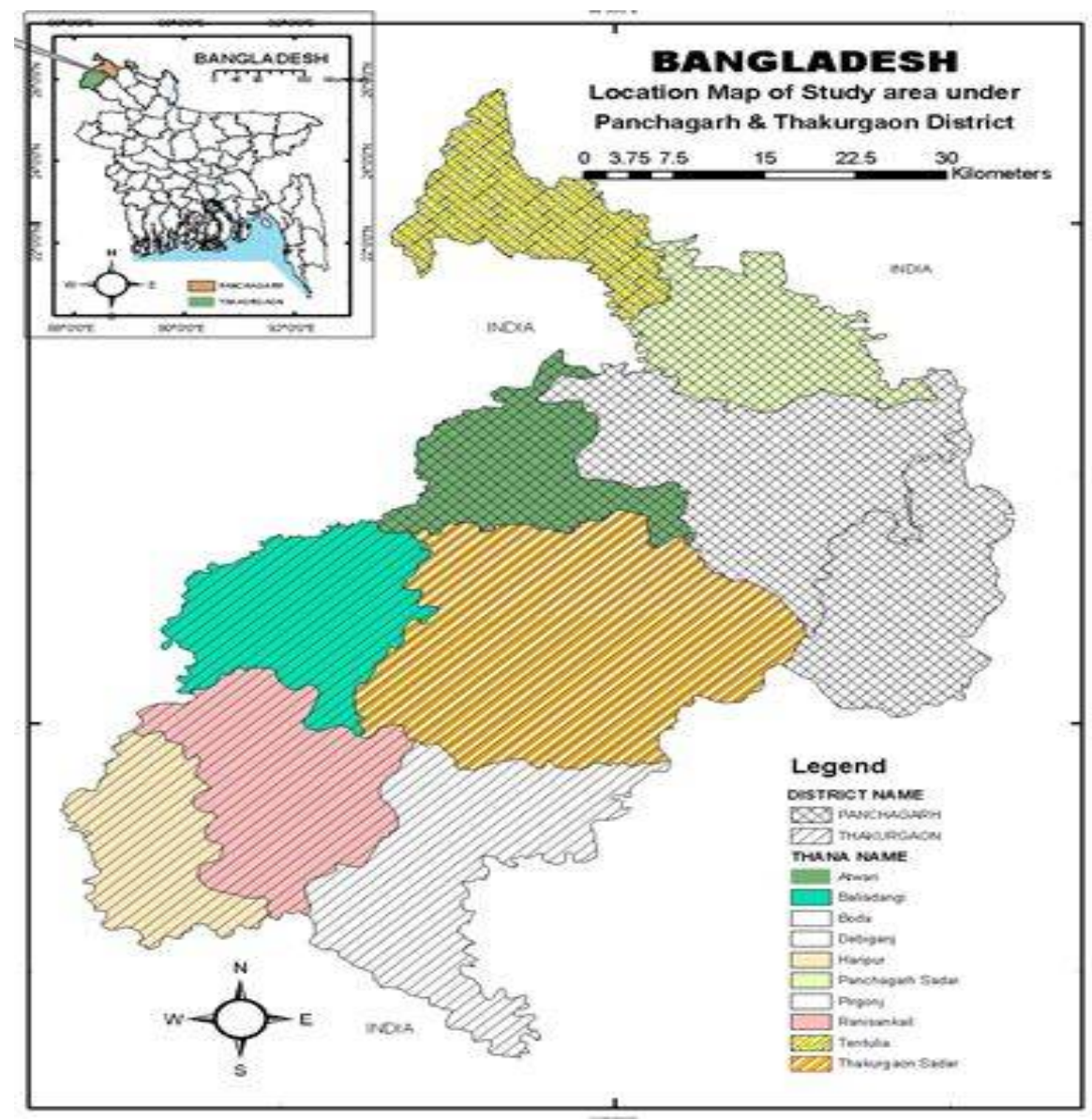

Fig. 1. Location map of the study sites.

land use for tea and orange. For each land utilization type, nine land quality parameters were considered: land type, relief, drainage, soil depth, waster recession conditions, texture, consistence, water supplying capacity and soil reaction etc. A digital database on tea and orange suitability assessment of the above areas was prepared using GIS tools (ArcGIS ver 9.1 developed by ESRI, USA). Respective polygon attribute tables of the digitized cover were calculated to 
estimate the suitable areas in the study sites. On the other hand, five representative soil pedons were also selected to complete the present study. The selected 5 soil series were: Bhajanpur, Ranisankail, Pirgachha, Domar and Dimla. Field characteristics of the soil series were studied based on the morphological properties of each soil horizon following the guidelines of FAO (2006). The parametric approaches were used to evaluate land and soil resources for its suitability as per Naidu et al. 2006. This approach is based on the comparison of the qualities of different land units with the requirements of actual and potential land use.

\section{Results and Discussion}

Many research workers (Nel and Bennie 1984, Mongia and Bandyopadhyay 1994, De Silva 2007) reported that a well aerated soil and a sufficiently deep profile to allow tap roots to penetrate to the desired depths $(1-2 \mathrm{~m})$ are required for growing tea and orange plants. Light to medium textured soils, free from stagnant water and non-sticky, pervious layers are preferred. Areas with a high water table should be avoided. The ground water table should preferably be below 1.5 meters. The Panchagarh and Thakurgaon districts belonging to the Himalayan piedmont plain are mostly suitable for tea and orange cultivation where the appropriate properties prevail (Table 1). Considering the above land qualities Ranisankail, Pirgachha, Bhajanpur, Domar and Dimla soil series were found to be most suitable for the cultivation of tea and orange. Ranisankail soil is moderately well drained, and dark brown sandy loam soil. The soil is strongly acidic and occurs on highland condition. Pirgachha soil is moderately well drained and brown loam soil. These are strongly acidic and occur on highland condition. Bhajanpur soil is moderately well drained, and very dark brown to black sandy loam. The soil is slightly acidic and occurs on highland condition. Domar and Dimla soil is moderately well drained, and pale brown or brown sandy loam. The soil is slightly acidic and occurs on highland condition. Using ArcGIS polygon attribute tables, it was found that out of 1,30,268 hectares in Panchagarh district, Bhajanpur soil series occupy about 3,624 ha, Pirgachha soil series occupy about 16,412 ha, Ranisankail soil series occupy about 4,631 ha, Domar and Dimla soil series occupy about 2,811 ha. On the other hand, ArcGIS polygon attribute tables showed that out of 1,81,025 hectares in Thakurgaon district, Ranisankail soil series occupy about 12,195 ha, Pirgachha soil series occupy about 17,552 ha, Domar and Dimla soil series occupy about 1,318 ha. Among the two districts, Tetulia and Atwari Upazilas occupy the vast areas for the cultivation of tea and orange (Table 2). It is important to note that these two Upazilas are very adjacent to Indian border or territory where India is cultivating tea and other citrus crops. Mongia and Bandyopadhyay (1994) noted that plantation crops like tea grows well under certain conditions of climatic and soil requirements. He also stated that tea and other citrus fruit grows well in the $\mathrm{pH}$ range of 4.0 to 5.5, well drained conditions with good aeration, under loamy texture and deep rooting depth. Rahman et al. (1999) also noted that land and soil characteristics along with climatic condition satisfy the criteria for the growth of orange in the Panchagarh and Thakurgaon districts.

Naidu et al. (2006) reported that the optimum mean daily temperature for the growth of tea or orange is 23 to $30^{\circ} \mathrm{C}$. The growth markedly reduced above $38^{\circ} \mathrm{C}$ and below $13^{\circ} \mathrm{C}$. Active root growth occurs when soil temperatures are higher than $12^{\circ} \mathrm{C}$. Strong wind is harmful to citrus plants, because flowers and young fruits fall off easily. High humidity increases the incidence of pests and diseases. An analysis of the agro-climatological data of Panchagarh and Thakurgaon regions indicates that the mean daily temperature and mean annual rainfall of this region satisfies the optimum requirements of horticultural crops (Hossain et al. 1999). Further analysis of temperature data reveals that the frequency of occurrence of temperature below $10^{\circ} \mathrm{C}$ is only 25 35 days. At this temperature, the offshoot sprouting will remain dormant. Again, the frequency of 
Table 1. Field characteristics of the soil pedons under the districts of Panchagarh and Thakurgaon.

\begin{tabular}{|c|c|c|c|c|c|}
\hline \multirow{2}{*}{$\begin{array}{l}\text { Field } \\
\text { characteristics }\end{array}$} & \multicolumn{5}{|c|}{ Soil pedons } \\
\hline & Bhajanpur & Ranisankail & Pirgachha & Domar & Dimla \\
\hline Color & $\begin{array}{l}\text { Very dark greyish } \\
\text { brown to light } \\
\text { olive or pale olive }\end{array}$ & $\begin{array}{l}\text { Dark yellowish } \\
\text { brown to light } \\
\text { olive brown }\end{array}$ & $\begin{array}{l}\text { Olive brown to } \\
\text { olive grey }\end{array}$ & $\begin{array}{l}\text { Olive brown to } \\
\text { light olive grey }\end{array}$ & $\begin{array}{l}\text { Brownish grey to } \\
\text { olive grey }\end{array}$ \\
\hline $\begin{array}{l}\text { Soil profile } \\
\text { depths }(\mathrm{cm})\end{array}$ & $0-120$ & $0-60$ & $0-69$ & $0-70$ & $0-71$ \\
\hline Soil pH & $\begin{array}{l}\text { Ranges from } 5.5- \\
6.5\end{array}$ & $\begin{array}{l}\text { Ranges from } \\
4.8-5.2\end{array}$ & $\begin{array}{l}\text { Ranges from } \\
4.6-5.6\end{array}$ & $\begin{array}{l}\text { Ranges from } \\
5.1-6.0\end{array}$ & $\begin{array}{l}\text { Ranges from } \\
5.7-6.0\end{array}$ \\
\hline Drainage & $\begin{array}{l}\text { Moderately well } \\
\text { drained }\end{array}$ & $\begin{array}{l}\text { Moderately well } \\
\text { drained }\end{array}$ & $\begin{array}{l}\text { Moderately } \\
\text { well drained }\end{array}$ & $\begin{array}{l}\text { Moderately well } \\
\text { drained }\end{array}$ & $\begin{array}{l}\text { Moderately well } \\
\text { drained }\end{array}$ \\
\hline Parent material & $\begin{array}{l}\text { Himalayan } \\
\text { piedmont plain }\end{array}$ & $\begin{array}{l}\text { Himalayan } \\
\text { piedmont plain }\end{array}$ & $\begin{array}{l}\text { Himalayan } \\
\text { piedmont plain }\end{array}$ & $\begin{array}{l}\text { Himalayan } \\
\text { piedmont plain }\end{array}$ & $\begin{array}{l}\text { Himalayan } \\
\text { piedmont plain }\end{array}$ \\
\hline $\begin{array}{l}\text { Relief or } \\
\text { topography }\end{array}$ & $\begin{array}{l}\text { Very gently } \\
\text { undulating } \\
\text { piedmont ridge }\end{array}$ & $\begin{array}{l}\text { Very gently } \\
\text { undulating } \\
\text { piedmont ridge }\end{array}$ & $\begin{array}{l}\text { Nearly level } \\
\text { piedmont ridge }\end{array}$ & $\begin{array}{l}\text { Nearly level } \\
\text { piedmont ridge }\end{array}$ & $\begin{array}{l}\text { Nearly level } \\
\text { piedmont ridge }\end{array}$ \\
\hline Texture & $\begin{array}{l}\text { Sandy loam to } \\
\text { sand }\end{array}$ & $\begin{array}{l}\text { Fine sandy loam } \\
\text { to loamy sand }\end{array}$ & $\begin{array}{l}\text { Loam to loamy } \\
\text { sand }\end{array}$ & $\begin{array}{l}\text { Fine sandy loam } \\
\text { to fine sand }\end{array}$ & $\begin{array}{l}\text { Sandy loam to } \\
\text { coarse sandy loam }\end{array}$ \\
\hline Structure & $\begin{array}{l}\text { Sub-angular } \\
\text { blocky to single } \\
\text { grained }\end{array}$ & $\begin{array}{l}\text { Sub-angular } \\
\text { blocky to single } \\
\text { grained }\end{array}$ & $\begin{array}{l}\text { Sub-angular } \\
\text { blocky to } \\
\text { single grained }\end{array}$ & $\begin{array}{l}\text { Sub-angular } \\
\text { blocky to single } \\
\text { grained }\end{array}$ & $\begin{array}{l}\text { Sub-angular } \\
\text { blocky to single } \\
\text { grained }\end{array}$ \\
\hline Consistence & $\begin{array}{l}\text { Friable under } \\
\text { moist condition; } \\
\text { slightly sticky to } \\
\text { non-plastic under } \\
\text { wet condition }\end{array}$ & $\begin{array}{l}\text { Friable under } \\
\text { moist condition; } \\
\text { slightly sticky to } \\
\text { non-plastic under } \\
\text { wet condition }\end{array}$ & $\begin{array}{l}\text { Friable under } \\
\text { moist } \\
\text { condition; } \\
\text { slightly sticky } \\
\text { to non-plastic } \\
\text { under wet } \\
\text { condition }\end{array}$ & $\begin{array}{l}\text { Very friable } \\
\text { under moist } \\
\text { condition; non } \\
\text { sticky and non- } \\
\text { plastic under } \\
\text { wet condition. }\end{array}$ & $\begin{array}{l}\text { Very friable under } \\
\text { moist condition; } \\
\text { non sticky and } \\
\text { non-plastic under } \\
\text { wet condition. }\end{array}$ \\
\hline Nature of pores & $\begin{array}{l}\text { Many, very fine } \\
\text { to fine tubular } \\
\text { pores }\end{array}$ & $\begin{array}{l}\text { Many, very fine } \\
\text { to fine tubular } \\
\text { pores }\end{array}$ & $\begin{array}{l}\text { Common very } \\
\text { fine to fine } \\
\text { tubular pores }\end{array}$ & $\begin{array}{l}\text { Many, very fine } \\
\text { to fine tubular } \\
\text { pores }\end{array}$ & $\begin{array}{l}\text { Many, fine to fine } \\
\text { tubular pores }\end{array}$ \\
\hline Boundary & Abrupt to wavy & $\begin{array}{l}\text { Clear to abrupt } \\
\text { smooth }\end{array}$ & $\begin{array}{l}\text { Clear to abrupt } \\
\text { smooth }\end{array}$ & $\begin{array}{l}\text { Clear to abrupt } \\
\text { smooth }\end{array}$ & $\begin{array}{l}\text { Clear to abrupt } \\
\text { smooth }\end{array}$ \\
\hline $\begin{array}{l}\text { USDA } \\
\text { nomenclature }\end{array}$ & $\begin{array}{l}\text { Humic } \\
\text { Endoaquepts }\end{array}$ & $\begin{array}{l}\text { Typic } \\
\text { Dystrudepts }\end{array}$ & $\begin{array}{l}\text { Aeric } \\
\text { Endoaquepts }\end{array}$ & $\begin{array}{l}\text { Typic } \\
\text { Dystrudepts }\end{array}$ & $\begin{array}{l}\text { Typic } \\
\text { Udorthents }\end{array}$ \\
\hline
\end{tabular}

Table 2. Tea and orange suitable areas under the districts of Panchagarh and Thakurgaon.

\begin{tabular}{lcccccc}
\hline \multirow{2}{*}{$\begin{array}{l}\text { Study } \\
\text { sites }\end{array}$} & $\begin{array}{c}\text { Total } \\
\text { areas (ha) }\end{array}$ & $\begin{array}{c}\text { Total } \\
\text { cultivable } \\
\text { areas (ha) }\end{array}$ & \multicolumn{2}{c}{$\begin{array}{c}\text { Highly suitable } \\
\text { areas }\end{array}$} & \multicolumn{2}{c}{$\begin{array}{c}\text { Moderately suitable } \\
\text { areas }\end{array}$} \\
\cline { 5 - 7 } & & & Hectare & $\%$ & Hectare & $\%$ \\
\hline Panchagarh Sadar Upazila & 33,844 & 26,580 & 11,937 & 45 & 14,651 & 55 \\
Tetulia Upazila & 18,919 & 16,820 & 12,858 & 76 & 3,970 & 24 \\
Atwari Upazila & 21,002 & 20,190 & 17,346 & 86 & 2,844 & 14 \\
Boda Upazila & 28,923 & 26,588 & 15,864 & 60 & 10,724 & 40 \\
Ranisankail Upazila & 28,769 & 27,429 & 18,165 & 67 & 9,264 & 33 \\
\hline
\end{tabular}


Table 3. Comparison of soil suitability criteria for tea cultivation in the study sites.

\begin{tabular}{|c|c|c|c|c|c|}
\hline & & \multirow[b]{2}{*}{ Units } & \multicolumn{2}{|c|}{ Rating* } & \multirow{2}{*}{$\begin{array}{l}\text { Potential values } \\
\text { in the study sites }\end{array}$} \\
\hline \multicolumn{2}{|c|}{ Soil-site characteristics } & & Highly & Moderately & \\
\hline $\begin{array}{l}\text { Climatic } \\
\text { regime }\end{array}$ & $\begin{array}{l}\text { Mean temperature } \\
\text { Total rainfall }\end{array}$ & $\begin{array}{l}{ }^{\circ} \mathrm{C} \\
\mathrm{mm}\end{array}$ & $\begin{array}{l}18-25 \\
1800-2000\end{array}$ & $\begin{array}{l}26-28 \\
1600-1800\end{array}$ & $\begin{array}{l}23 \text { to } 30 \\
1800-2100\end{array}$ \\
\hline $\begin{array}{l}\text { Moisture } \\
\text { availability }\end{array}$ & $\begin{array}{l}\text { Length of growing } \\
\text { period }\end{array}$ & Days & $>240$ & $240-180$ & $210-230$ \\
\hline $\begin{array}{l}\text { Oxygen } \\
\text { availability } \\
\text { to roots }\end{array}$ & Soil drainage & Class & $\begin{array}{l}\text { Well } \\
\text { drained }\end{array}$ & $\begin{array}{l}\text { Moderately } \\
\text { to } \\
\text { imperfectly } \\
\text { drained }\end{array}$ & $\begin{array}{l}\text { Moderately well } \\
\text { drained }\end{array}$ \\
\hline $\begin{array}{l}\text { Rooting } \\
\text { conditions }\end{array}$ & $\begin{array}{l}\text { Effective soil } \\
\text { depths }\end{array}$ & $\mathrm{cm}$ & $>150$ & $100-150$ & $75-150$ \\
\hline \multirow[t]{2}{*}{$\begin{array}{l}\text { Nutrient } \\
\text { availability }\end{array}$} & Soil pH & $\begin{array}{c}1: 2.5 \\
\text { (soil : water) }\end{array}$ & $4.5-5.0$ & $5.1-6.0$ & $4.8-5.4$ \\
\hline & Texture & Class & $\begin{array}{l}\text { scl, l, cl, sl, } \\
\text { sil }\end{array}$ & c, sicl, sic & $\begin{array}{l}\text { Sandy loam to } \\
\text { loam }\end{array}$ \\
\hline
\end{tabular}

Source: Naidu et al. (2006)*

Table 4. Comparison of soil suitability criteria for orange cultivation in the study sites.

\begin{tabular}{|c|c|c|c|c|c|}
\hline \multirow{2}{*}{$\begin{array}{c}\text { Soil-site } \\
\text { characteristics }\end{array}$} & & \multirow[b]{2}{*}{ Units } & \multicolumn{2}{|c|}{ *Rating } & \multirow{2}{*}{$\begin{array}{l}\text { Potential } \\
\text { values in the } \\
\text { study sites }\end{array}$} \\
\hline & & & $\begin{array}{c}\text { Highly } \\
\text { suitable (S1) }\end{array}$ & $\begin{array}{c}\text { Moderately } \\
\text { suitable (S2) }\end{array}$ & \\
\hline \multirow{3}{*}{$\begin{array}{l}\text { Climatic } \\
\text { regimes }\end{array}$} & Mean & ${ }^{0} \mathrm{C}$ & $28-30$ & $31-35$ & 23 to 30 \\
\hline & temperature & & & $24-27$ & \\
\hline & Total rainfall & $\mathrm{mm}$ & $1200-1800$ & $1000-1200$ & $1800-2100$ \\
\hline $\begin{array}{l}\text { Moisture } \\
\text { availability }\end{array}$ & $\begin{array}{l}\text { Length of } \\
\text { growing period }\end{array}$ & Days & $240-265$ & $180-240$ & $210-230$ \\
\hline \multirow[t]{2}{*}{$\begin{array}{l}\text { Oxygen } \\
\text { availability to } \\
\text { roots }\end{array}$} & Soil drainage & Class & Well drained & $\begin{array}{l}\text { Moderately to } \\
\text { imperfectly } \\
\text { drained }\end{array}$ & $\begin{array}{l}\text { Moderately } \\
\text { well drained }\end{array}$ \\
\hline & $\begin{array}{l}\text { Depth of water } \\
\text { table }\end{array}$ & $\mathrm{cm}$ & $>250$ & $\begin{array}{l}250-300 \\
250-150\end{array}$ & $200-300$ \\
\hline \multirow[t]{3}{*}{$\begin{array}{l}\text { Rooting } \\
\text { conditions }\end{array}$} & $\begin{array}{l}\text { Effective soil } \\
\text { depth }\end{array}$ & $\mathrm{cm}$ & $>150$ & $100-150$ & 75 to 150 \\
\hline & $\begin{array}{l}\text { Presence of hard } \\
\text { pan in sub soil }\end{array}$ & $\mathrm{cm}$ & $>200$ & $200-150$ & $\begin{array}{l}\text { No pan in the } \\
\text { sub soil }\end{array}$ \\
\hline & $\begin{array}{l}\text { Presence of } \\
\text { gravel in sub soil }\end{array}$ & $\%$ & Non gravelly & $15-35$ & $\begin{array}{l}\text { No gravel in } \\
\text { the sub soil }\end{array}$ \\
\hline \multirow[t]{2}{*}{$\begin{array}{l}\text { Nutrient } \\
\text { availability }\end{array}$} & Soil pH & $\begin{array}{l}1: 2.5 \\
\text { (soil : water) }\end{array}$ & $6.5-7.5$ & $\begin{array}{l}5.5-6.4 \\
7.6-8.0\end{array}$ & $4.8-5.4$ \\
\hline & Texture & Class & $\mathrm{scl}, 1, \mathrm{sicl}, \mathrm{cl}, \mathrm{s}$ & sc, sicl, sic & $\begin{array}{l}\text { Sandy loam to } \\
\text { loam }\end{array}$ \\
\hline
\end{tabular}

Source: Naidu et al. (2006)* 
occurrence of temperature $>40^{\circ} \mathrm{C}$ is only 0.5 - 10 days. An analysis of long term rainfall data and stored soil moisture to one meter depth indicates that there is a period of moisture shortage or dry period of maximum 50 - 60 days in this region (Manalo 1975). On the other hand, there is a humid or wet period when the total rainfall is continuously greater than the potential evapotranspiration of crops. During this period, excess water from the soil profile needs to be drained out timely. A Comparative study of climatic, hydrological, land and soil characteristics indicates that the study sites are most favorable for the farming of tea and orange (Tables 3-4), respectively. The above study revealed that soil and climatic characteristics of Panchagarh and Thakurgaon districts of Bangladesh are most suitable for growing tea and orange.

\section{References}

Buol SW, Southard RJ, Graham RC and McDaniel PA 2003. Soil Genesis and Classification. Wiley Blackwell publishing house. pp. 1-360.

Coleman AL and Galbraith JM 2000. Using GIS as an agricultural land use planning tool. Bulletin No. 2, Department of Crop and Soil Environmental Science, Virginia Tech. Blacksburg, Virginia. USA.

De Silva LDSM 2007. The effects of soil amendments on selected properties of tea soils and tea plants (Camellia sinensis L.) in Australia and Sri-Lanka. Ph.D. dissertation, James Cook University, Australia. pp. 1-154.

Dumanski J, Phipps M and Huffman E 1987. A study of relationships between soil survey data and agricultural land use using information theory. Canadian Journal of Soil Science 67: 95-102.

FAO 1983. Guidelines: Land evaluation for Rain fed Agriculture Soils. Bulletin 52, Rome.

FAO 2006. FAO guidelines for soil profile description. Food and Agriculture Organization, Rome. p. 85.

Gahlod NS, Ravi SB and Arya VS 2017. Land-site suitability evaluation for tea, cardamom and rubber using Geo-spatial technology in Wayanad district, Kerala. Journal of Applied and Natural Science 9(3): 14401447.

Hossain MM, Uddin MJ and Sultana KA 1999. Environmental and fertility characteristics of soils from Thakurgaon Sadar Thana under Old Himalayan Piedmont Plain. J. Remote Sensing and Environment. Vol. 3, Dhaka.

Jenny H 1980. The Soil Resources: Origin and Behavior. Springer-Verlag. New York, USA. pp. 377.

Maji AK, Nayak DC, Krishna NDR, Srinivas CV, Kamble K, Reddy GPO and Velayutham M 2001. Soil Information System of Arunachal Pradesh in a GIS environment for land use planning. International Journal of Applied Earth Observation and Geoinformatics 3: 69-77.

Manalo EB 1975. Agro-climatic Survey of Bangladesh. Vol. 1. International Rice Research Institute (IRRI). Los Banos, Philippines. $361 \mathrm{p}$.

Mongia AD and Bandyopadhyay 1994. Soils of the Tropics. Vikas Publishing House Pvt Ltd. New Delhi. pp. 134-146.

Naidu LGK, Ramamurthy V, Challa O, Hegde R and Krishnan P 2006. Soil-site suitability criteria for major crops. NBSS Publ. No. 129. NBSS \& LUP, Nagpur, India. pp. 118.

Nel DJ and Bennie ATP 1984. Soil factors affecting tree growth and root development in a citrus orchard, South African Journal of Plant and Soil 1(2): 39-47.

Rahman MM, Huq MM and MKH Dewan 1999. Suitability of orange cultivation in Panchagarh and Thakurgaon districts. Asia Pacific J. Env. Dev. 6(1) pp 47-55.

Sahu N, Reddy GP, Obi, Kumar N and Nagaraju MSS 2014. High resolution remote sensing, GPS and GIS in soil resource mapping and characterization - A review. Agricultural Review 36(1): 14-25.

Sys C, Ranst V, Debaveye J and Beenaert F 1993. Land Evaluations. Part III Crop Requirements. Agri. Publication No. 7, ITC, Ghent.

Uddin MJ 2000. Land Use Planning Policy for Sustainable Agricultural Development. SAIC Newsletter publication. Vol. 10, No. 2, Issue: April-June, Dhaka.

Manuscript received on 9 December, 2018; revised on 29 March, 2020) 